Зазірний А.А., Аросланкін О.О.

\title{
УЗГОДЖЕННЯ ТЕХНІЧНОГО ТА БІОЛОГІЧНОГО СЕГМЕНТІВ ЕРГАТИЧНОЇ СИСТЕМИ «СУДНОВОДІЙ - СУДНО» 3 ВИКОРИСТАННЯМ НЕЧІТКОГО НЕЙРОМЕРЕЖЕВОГО ПІДХОДУ
}

У статті проаналізовано причини виникнення та наслідки небезпечних ситуацій під час руху судна та визначено необхідність застосування індивідуально-адаптованого підходу для підтримки прийняття рішення. Запропоновано підхід щзодо оперативного контролю та підтримки дій судноводія, в основі якого лежить використання індивідуально адаптованої нейромережевої моделі його діяльності, щзо реалізує особливості управлінських реакцій при небезпечних режимах плавання. Такі моделі дозволяють здійснювати виявляти та перехоплювати помилки судноводія в процесі реалізації прийнятого рімення. Прогнозу точності приведення судна в термінальну точку траєкторії маневру на основі поточного вектору стану, забезпечує своєчасність визначення ситуаџії. Складність завдання прогнозування ситуачій в небезпечних режимах управління за рахунок визначення помилок судноводія виникає через неможливість чіткої постановки відповідності змін вхідних $i$ вихідних параметрів стану, в якому знаходиться або до якого прагне об'єкт управління. Найважливіша властивість нечітких нейронних мереж, щьо свідчить про їх великий потенціал в галузі прогнозування та підтримки дій судноводія, складається в можливості паралельної обробки інформації усіма нейронами. Завдяки иій здатності при великій кількості міжнейронних зв'язків досягається одночасно обробка значного обсягу вимірювальної інформачїі, що надходить вимірювальної інформачії в реальному масштабі часу. Структура та параметри нечітких нейромережевих моделей визначаються на основі обробки даних попередніх дій, виконаних конкретним судноводієм на конкретному судні, та безперервно уточняються по мірі надходження нових даних. Використана класифікація помилок судноводія при прийнятті рімень в прочесі управління суден дозволило розробити процедури реагування на них. Запропонований підхід дозволяе узгодити технічний та біологічний сегмент ергатичної системи «судноводій — судно» та знизити вплив людського фактору в небезпечних ситуаціях під час руху судна.

Ключові слова: судно, судноводій, ситуачія небезпечного зближення, навігаційна обстановка, ергатична система, людський фактор.

Постановка проблеми. Завдання оперативного контролю та аналізу управлінських дій судноводія після прибуття в порт, грають одну з найважливіших ролей в області підвищення безпеки судноплавства та ефективності використання ресурсів судна. На сьогоднішній день тенденції розвитку в області судноплавства характеризуються безперервним розширенням кола завдань, що вирішуються екіпажом судна. Ця обставина поряд 3 такими чинниками, як підвищення технічних характеристик суден, ускладнення комплексу суднового обладнання та високі вимоги до рівня безпеки призвело до підвищення психофізіологічного навантаження на судноводія в процесі плавання та визначає підвищені вимоги до його підготовки. Вирішення завдання узгодження технічного та біологічного сегментів ергатичної системи «судноводій-судно», як зазначено у роботах [1-3], дозволить підвищити рівень безпеки судноплавства та ефективності експлуатації судна. У цій статті запропоновано 
підхід до вирішення завдання узгодження, шляхом підвищення ефективності управлінських дій судноводія на основі індивідуально-адаптованого оперативного контролю та аналізу його управляючих впливів. Зв'язок завдань оперативного контролю та аналізу з проблемою узгодження технічного і біологічного сегментів визначається тим, що судноводій (біологічний сегмент) є по суті основним елементом, який впливає на судно (технічний сегмент), здійснюючи безперервне управління. При цьому, оскільки об'єктом і контролю, і аналізу є одна і та ж сутність - дії судноводія при управлінні судном, доцільно розглядати спільне рішення цих задач. Саме тому розробка загальних підходів, методів, алгоритмів і моделей, які могли б служити базою для вирішення перерахованих вище завдань $є$ актуальною задачею.

Аналіз останніх досліджень і публікацій. У роботах [4-6] висвітлені питання, пов'язані зі створенням інтелектуальних систем управління рухом судна. Аналіз досліджень в даній галузі показує, що створення систем підтримки прийняття рішення передбачає врахування людського фактору, як однієї з головних причин аварійності в сучасному судноплавстві. В умовах, що склалися створення СППР судноводія, що дозволяє мінімізувати вплив людського фактору на процеси управління судном, $\epsilon$ актуальною науковою і прикладною задачею. Ситуації, що виникають на практиці при русі судна в обмежених умовах або в умовах небезпеки, містять велику кількість невизначеностей різного характеру в діапазоні від неточності вимірювальних приладів до нечіткості оцінки допустимого відстані зближення і неоднозначності Міжнародних правил попередження зіткнення суден (МППСС-72), що використовують як основний нормативний документ, який регулює рух судна [7].

Крім того, зміна зовнішніх впливів і змінних обмежень і змінюються елементи руху інших суден і навігаційних небезпек, які перебувають в районі плавання, ставлять необхідність динамічної коригування обраного алгоритму управління судном [8]. в роботах авторів [9-12] була сформульована концепція системи підтримки судноводія, в основі якої лежить індивідуально-адаптована модель його управляючих впливів, були запропоновані методи та алгоритми формування таких моделей.

Мета дослідження полягає в підвищенні оперативності та обгрунтованості прийняття рішення судноводієм для забезпечення безпеки судноводіння.

Основні результати дослідження. Відмітимо, що незважаючи на різні причини виникнення та наслідки небезпечних ситуацій під час руху судна, переважна більшість аварій, були викликані помилками судноводіїв та берегових працівників, пов'язаних 3 рухом суден (рис.1). Це особливо важливо, оскільки серед причин зниження безпеки мореплавання та аварійності домінує «людський фактор»: число аварій 3 вини судноводіїв суден досягає за даними різних авторів 75-80 \% [13].

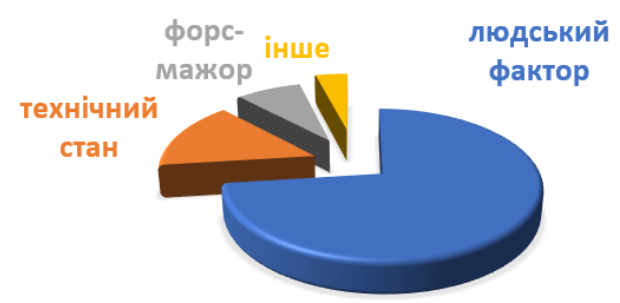

Рисунок 1 - Статистика аварій по причинам їх виникнення

До важких порушень заходів безпеки в судноплавстві можна віднести випадки, коли наслідки небезпечної ситуації призводять до морських катастроф, а саме до загибелі суден, людських жертв, екологічних проблем. Всі аварії суден, викликані людським фактором, можуть бути розділені на такі групи: 
- навігаційні (викликані не компетентністю судноводія та/або екіпажу, відсутністю відповідного досвіду, вміння приймати швидкі та обгрунтовані рішення у небезпечних ситуаціях);

- технологічні (викликані порушенням міцності корпусу судна, його механізмів, втратою остійності, переміщенням вантажів, виникненням пожежі, попаданням води у внутрішні відсіки);

- технічні (викликані неналежним технічним обслуговуванням та/або експлуатацією судна).

На сучасному етапі, основним напрямком розвитку судноплавства для зниження аварійності $є$ продовження автоматизації процесів управління судном, що значно видозмінюе діяльність судноводія та екіпажу. Управління судном та судовими системами спрощується, але різко зростають навантаження, пов'язані з прийомом та обробкою інформації щодо контролю за роботою систем. Все більше і більше підвищується психологічне навантаження на членів екіпажу.

Суднові інформаційні системи (CIC) є тією частиною суднового обладнання, 3 якими судноводій безпосередньо взаємодіє. Взаємодія судноводія з СІС можна уявити як взаємодію двох інформаційних процесорів - людини та ЕОМ, що обмінюються даними за допомогою інтерфейсу з вузькою смугою пропускання (від 2-6 до 10 біт / с).

Під ергатичною системою «судноводій - судно» (рис. 2) розуміється комплекс, що забезпечує вплив судноводія на судно та його системи за допомогою різних засобів та органів управління, а з іншого боку, інформування судноводія про стан судна за допомогою суднових інформаційних систем.

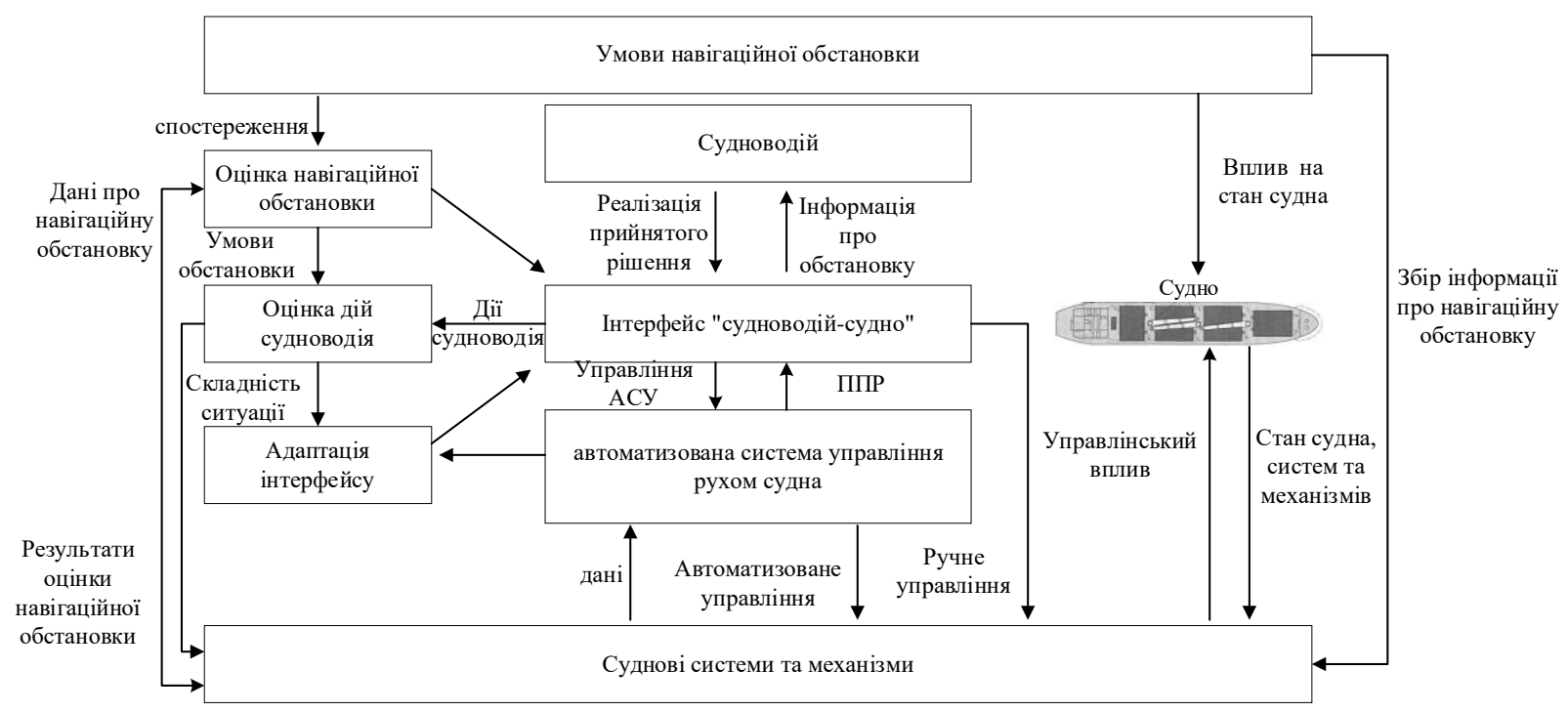

Рисунок 2 - Структурна схема ергатичної системи «судноводій - судно» зі змінною структурою

Основними принципами при розробці ергатичної системи зі змінною структурою «судноводій - судно» $є$ :

- виконання вимог ергономіки;

- логіка роботи системи повинна бути зрозумілою для судноводія, тобто вона повинна описуватися набором доступних правил;

- за безпеку і ефективність плавання відповідає судноводій. У судноводія повинна бути можливість відключити автоматичний режим та перейти на ручний, при цьому автоматика не повинна впливати на робочий режим; 
- при відмові автоматики повинні бути створені умови для виконання завдання судноводієм. Ручний режим повинен пересилювати автоматичний;

- якщо судноводій вибрав потенційно небезпечний режим, автоматизована система повинна його про це попередити, та у небезпечних випадках реагувати;

- судноводій постійно повинен бути обізнаний про всі завдання, які виконуються системою, і повинен усвідомлювати, в якому стані знаходиться кожне із завдань;

- система повинна інформувати судноводія про режим роботи і свій стан (справна / несправна);

- у судноводія повинна бути можливість доступу до вихідної інформації з метою перевірки безпомилковості роботи системи при відображенні інформації;

- на всіх етапах плавання судноводій повинен бути постійно включений в контур управління судном та його системами;

- автоматизацію функції слід здійснювати тільки в тому випадку, коли підвищується ймовірність помилки судноводія;

- принцип цільової спрямованості - максимальна ймовірність рішення екіпажем поставленого завдання;

- принцип мінімуму часових витрат

- при виконанні алгоритмів роботи екіпажу, окремих членів екіпажу мінімізуються витрати часу;

- принцип оптимальної функціональності при ергатичної системи зі змінною структурою.

В ергатичній системі інтерфейс «судноводій - судно» в залежності від ситуації, що складається в під час руху судна повинен адаптуватися в частині обсягу наданої інформації, способів іiї надання, рівня автоматизації функцій (коли і що потрібно знати судноводію, в якій формі слід представляти йому інформацію і за допомогою яких засобів: візуальних, звукових, тактильних, мовних або силовим впливом на штурвал); Інтерфейс фільтрує інформацію і визначає порядок її надання (встановлює пріоритети). Інтерфейс оцінює дії судноводія, навантаження на нього та здатність впоратися 3 негативними умовами обстановки, підлаштовується під стан пілота.

У міру накопичення досвіду судноводій набуває багато індивідуальних, тільки йому властивих особливостей отримання інформації. Він легко може розпізнавати типи ситуації та може передбачити хід їх подальшого розвитку. В області виконавчих функцій судноводій може адоптивно використовувати різні методи виконання робіт. Проте судноводій поступається автоматичним системам в швидкості та точності обробки інформації, реалізації управлінських функцій. Можливості судноводія обмежені його психофізіологічними особливостями організму. Небезпечні ситуації, пов'язані з діяльністю судноводія, що кваліфікуються як "помилка судноводія" може бути i не були такими, якщо оцінити їх 3 точки зору меж можливостей людського організму.

Розглянемо можливості використання нечітких нейронних мереж як індивідуально-адаптованих нейромережевих моделей судноводія для вирішення завдань оперативного контролю та аналізу його управляючих впливів 3 метою узгодження технічного та біологічного сегментів системи "судноводій-судно".

Під моделлю дій судноводія буде розуміється залежність $\delta(S, d)$, яка для кожного значення дальності $d$ до деякої заздалегідь відомої точки маршруту для системи «судноводій-судно» визначає прогнозовану точність приведення судна в деяку термінальну точку, що характеризується деякою скалярною величиною $\delta$.

Модель $\delta(S, d)$ представляється у вигляді нечіткої нейронної мережі типу ANFIS. Індивідуальні особливості керуючих реакцій судноводія проявляються в структурі та параметрах мережі, які визначаються за результатами процедури «навчання» з використанням даних, накопичених в попередніх плаваннях. 
Параметри нечітких нейромережевих моделей періодично уточняються по мірі надходження нових даних в результаті виконання судноводієм своїх обов'язків, 3 урахуванням накопиченого досвіду та зміни кваліфікації. Для визначення параметрів нейронної мережі введемо поняття режиму плавання. Під режимом плавання в даній роботі розуміються етапи руху судна, в яких судноводій переходить 3 одного алгоритму дій до іншого. Наприклад плавання у відкритих водах, плавання в обмежених навігаційних умовах, етапи приходу суден у порт та вихід у море, та ін.. В якості небезпечного режиму плавання будуть розглядатися ситуації розходження суден. Цей режим є найбільш суворо регламентованим, що дозволяє припустити, що якщо індивідуальні особливості управління судном проявляються на ньому, то на інших режимах плавання ці прояви будуть ще більш істотним. Для судноводія будемо застосовувати наступний параметр, що характеризує безпеку приведення судна в термінальну точку траєкторії при виконанні маневру розходження в ситуації небезпечного зближення (зіткнення) [14]:

$$
\eta_{i}=\sqrt{\frac{D_{3 \sigma}^{\min }}{d_{s a f}^{\min }}+\frac{T_{3 \sigma}^{\min }}{t_{m v}^{\min }}},
$$

де $D_{з б}^{\min }, T_{3 б}^{\min }-$ відповідно дистанція та час найкоротшого зближення;

$d_{s a f}^{\min }, t_{m v}^{\min }-$ відповідно мінімально-допустима дистанція найкоротшого зближення та час гальмування або циркуляції.

Вибір оптимально безпечного маневру, тобто значень швидкості $V$ та курсу $K$ виконується шляхом пошуку відповідних значень керуючих впливів $u \in U$ (кут відхилення стерна та обороти двигуна) за допомогою нечіткої нейромережевої моделі, що враховує правила МПСС-72 та динаміку руху судна.

Наявність індивідуально-адаптованих нечітких нейромережевих моделей судноводія у вигляді залежностей $\delta(S, d)$ дозволяє реалізувати контроль, а при необхідності підтримку прийняття рішення судноводієм. На рис. 2 наведена схема контролю та підтримки прийняття рішення судноводієм при виконанні маневру розходження на основі його індивідуально-адаптованої нечіткої нейромережевох моделі. Вибір структури наведеного на рисунку алгоритму обумовлений тим, що його використання ні в якому разі не повинно призводити до збільшення навантаження на судноводія.

Ця вимога є принциповим обмеженням, що впливає на спосіб практичної реалізації функції підтримки. Тому, формування рекомендацій, спрямованих на підтримку прийняття рішення судноводієм, має проводиться лише у разі, коли виникає реальна небезпека виникнення небезпечних ситуацій, викликаних як діями судноводія оперуючого судна так і діями судноводія судна-потенційної загрози. В рамках наведеної на рис. 3 схеми момент активізації алгоритмів підтримки прийняття рішення визначається умовами:

$$
\eta_{i}<1
$$

що свідчить про небезпеку виникнення небезпечної ситуації зближення (зіткнення). Дана нерівність має місце, якщо поточні дії судноводія не забезпечують заданих вимог МППСС- 72 . У цих випадках виникає необхідність підтримки прийняття рішення дій судноводія для виключення небезпеки зіткнення. Проблема вибору конкретного способу реалізації рекомендацій, спрямованих на підтримку дій судноводія, є складним 
комплексним завданням, що виникає в процесі проектування будь-якої людиномашинної системи.

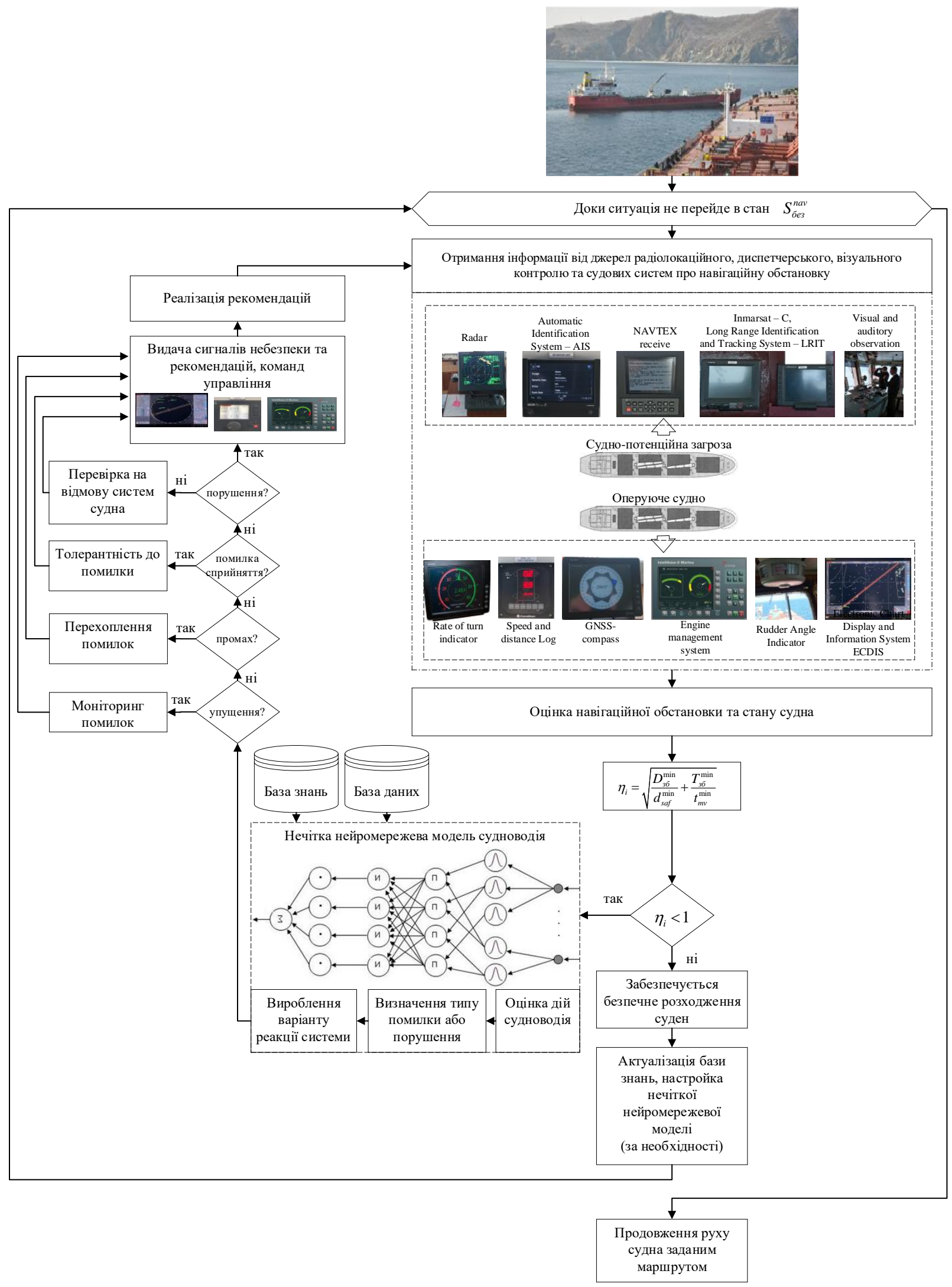

Рисунок 3 - Схема методу індивідуально-адаптованого контролю і підтримки прийняття рішення судноводієм при виконанні маневру розходження 
Аналіз наслідків небезпечних ситуацій показує, що в дуже схожих умовах навігаційної обстановки результат дій судноводія буває зовсім різний. Тобто, рішення, прийняті одним і тим же судноводієм, можуть змінюватися в широкому діапазоні в залежності від впливу прямих і непрямих факторів та випадкових впливів навіть при схожих умовах обстановки. Відповідно, усвідомлення того, як помилки судноводіїв впливають на їх здатність приймати рішення дозволять.

Помилки не $є$ аномальною поведінкою, вони представляють собою природний побічний результат практично всіх зусиль людини. Повністю їх уникнути в діяльності судноводія не вдається, але вони піддаються контролю за допомогою застосування удосконалення систем управління судном, відповідної підготовки та належної правки процедур. Помилки судноводія можна класифікувати так:

- промахи (дії, які виконані не так як планувалося)

- упущення (не врахування того чи іншого фактору, або пропуску важливої інформації при прийнятті рішення)

- помилки сприйняття (помилки розпізнання ситуації, коли судноводій приймає рішення на основі власних суджень, що не відповідають реальній навігаційній обстановці).

Всі ці помилки радикально відрізняються від порушень, хоча і ті й інші можуть призвести до небезпечної ситуації. Порушення - це навмисний акт судноводія. Повне виключення помилок в діяльності судноводія неможливо. Проблема не тільки в тому, щоб запобігати помилкам, але і в тому, щоб навчитися безпечно долати неминучі помилки.

При виникненні ситуації небезпечного зближення (зіткнення) система може реагувати на помилки судноводія та/або екіпажу так:

a) Моніторинг помилок (зниження частоти помилок за рахунок моніторингу факторів, що сприяють їх виникненню, та при підвищенні ймовірності помилки подавати відповідні сигнали).

б) Перехоплення помилок (помилка вже зроблена, але виявлена системою до прояву своїх негативних наслідків, та виробленні відповідні рекомендації щодо іï виправлення).

в) Толерантність до помилок (здатність системи управління реагувати на помилку для попередження негативних наслідків, резервування управління).

Реалізація наведених вище шляхів зменшення помилки можливе в системах управління судном тільки при розробці та впровадження СППР судноводія при виникненні небезпечних ситуацій з урахуванням стресу та дефіциту часу на прийняття рішення.

Вивчення поведінки судноводія в небезпечних ситуаціях зближення (зіткнення) в реальних умовах і на тренажері, дозволяє встановити, що надійність дій судноводія визначається характеристиками сигнальної інформації, а саме здатністю привернути увагу від чого залежать ймовірність та час виявлення сигналів, і їх змісту, що впливає на надійність розпізнання поточної навігаційної обстановки та прийняття рішення [15]. Для ефективності дій екіпажу важливо, щоб сам сигнал, по можливості, мінімально відволікав від судноводіння, але сприяв при цьому організації адекватних дій.

Оскільки для роботи судноводія при управлінні судном, характерна підвищена концентрація уваги на індикаторах джерел інформації про навігаційну обстановку, а також про стан та рух власного судна, на що приділяється до 70-80\% часу. Тому можна, зберігаючи його штатну базову компоновку, формувати сигнали, що реалізують принцип індивідуально-адаптованої допомоги судноводію. Найбільш просто ця стимулююча корекція реалізується за допомогою додавання поправок для курсу, швидкості, кута повороту стерна судна тощо.

Висновки. В умовах небезпечної ситуації, підтримка прийняття рішень судноводія стає ключовим елементом, що забезпечує зниження впливу людського фактору на процеси управління судном та підвищує безпеку судноводіння. Розробка автоматизованих систем управління в судноводінні вимагає врахування особливостей взаємодії людини з технічними засобами управління судном. Практичне впровадження АСУ має здійснюватися шляхом її повної інтеграції з існуючими засобами електронної навігації судна. Запропоновано підхід побудови системи підтримки прийняття рішення 
судноводія, на основі індивідуально-адаптованих нечітких нейромережевих моделей. Розроблено, індивідуально-адаптованого контролю і підтримки прийняття рішення судноводієм при виконанні маневру розходження, що враховують помилки судноводія при уникненні зіткнення в умовах виконання вимог МППСС-72. Подальший розвиток індивідуально-адаптованого підходу потребує вдосконалення засобів інформаційної взаємодії технічних засобів управління рухом судна та берегових навігаційних систем. Важливим напрямком подальших досліджень в області створення автоматизованих систем управління судном стануть питання координації взаємодії суден в районі маневрування.

\section{ЛІТЕРАТУРА}

1. Себряков Г.Г. Моделирование деятельности человека-оператора в полуавтоматических системах управления динамическими объектами / Г.Г. Себряков // Мехатроника, автоматизация, управление. - № 4. - 2010. - С.17 - 29.

2. Шептуха Ю. М. К вопросу синтеза эргатической системы принятия решений о маневре безопасного расхождения судов / Ю.М. Шептуха // Кибернетика и вычислительная техника. - № 84. - 1989. - С. 43-45.

3. Смоленцев С.В. Человеческий фактор и пути обеспечения безопасности мореплавания с использованием динамических семантических сетей / С. В. Смоленцев // Морские информационные технологии. - С.Пб.: Элмор, 2002. Вып.2. - С. 4-8.

4. Бень А.П. Методы оценки опасности траектории движения судов в системах поддержки принятия решений / А. П. Бень // Вестник ХНТУ : сб. науч. трудов Херсонского национального технического университета. - 2009. - Вып. 1 (34). C. 429-433.

5. Бень А.П. Принципи побудови систем підтримки прийняття рішень судноводія / А.П. Бень // Матеріали другої науково-практичної конференції «Сучасні інформаційні та інноваційні технології на транспорті (MINTT-2010)» (25-27 травня 2010 р., Херсон, ХДМІ.) - Т.1. - С. 8-10.

6. Мальцев А.С. Интеллектуальные гибридные системы поддержки принятия решений при расхождении судов / А.С. Мальцев // Судовождение : Сб. научн. Трудов / ОНМА, Вып. 11. - Одесса : ИздатИнформ, 2006. - С. 74-86

7. Цымбал Н.Н., Бужбецкий Р.Ю. Учет ограничений МППСС-72 при выборе маневра расхождения судов / Н.Н. Цымбал // Судовождение. - Вып. 11. - 2006. C. $134-138$.

8. Бурмака И.А. Поликритериальное управление процессомс удовождения / И.А. Бурмака, С.А. Дудник // Судовождение. - Вып. 12. - 2006 - С. 26-30.

9. Ермаков С. В. Управление риском чрезвычайных ситуаций на основе прогнозирования и минимизации влияния человеческого фактора на навигационную безопасность плавания судна : дис. ... кандидата техн. наук 05.26.02 / Ермаков Сергей Владимирович . Калининград, 2018. - 208 с.

10. Борсук С. П. Ергономічні основи проактивної кваліметрії закономірностей прояву людського чинника в аеронавігаційних системах : дис. ... кандидата техн. наук 05.01.04 / Борсук Сергій Павлович. Харків, 2019. - 378 с.

11. Тихонов І. В. Методологічні основи поліергатичного забезпечення навігації та управління рухом водних транспортних засобів (цільова технологія безпеки) : дис. ... кандидата техн. наук 05.22.13 / Тихонов Ілля Валентинович. Київ, 2018. - 441 с.

12. Смоленцев С. В. Автоматический синтез решений по расхождению судов в море / С. В. Смоленцев // Вестник Государственного университета морского и речного флота имени адмирала С. О. Макарова. - 2016. - № 2 (38). - С. 7-15.

13. Пипченко А.Д. Анализ аварийности мирового флота 2005-2015 / А.Д. Пипченко // Судовождение. - 2017. - Вып.27. - С. 159-168.

14. Вагущенко Л. Л. Поддержка решений по расхождению с судами / Л.Л. Вагущенко Одесса: Феникс, 2010. - 229 с. 
15. Астреин В. В. Методология анализа и синтеза сложных активных технических систем и ее реализация в системе безопасности судовождения: дис. ... доктора техн. наук : 05.13.01 / Астреин Вадим Викторович. Краснодар, 2017. - 311 с.

\section{REFERENCES}

1. Sebryakov, G.G. (2010) Modeling human operator activity in semi-automatic control systems for dynamic objects. Mechatronics, automation, management. № 4. P.17 - 29.

2. 2. Sheptukha, Yu. M. (1989) On the synthesis of an ergatic system for making decisions on the maneuver of safe separation of ships... Cybernetics and Computing. № 8. P. 4345.

3. Smolentsev, S.V. (2002) The human factor and ways to ensure the safety of navigation using dynamic semantic networks. Marine information technology. Vol. 2. P. 4-8.

4. Ben, A.P. (2009) Methods for assessing the hazard of the trajectory of the movement of ships in decision support systems. Bulletin of KhNTU: Sat. scientific. Proceedings of the Kherson National Technical University. Vol. 1 (34). P. 429-433.

5. Ben, A.P. (2010) Principles of Incentive Systems for Acceptance of Shipbuilding Solutions Materials of another scientific-practical conference "Current information and innovation technologies in transport (MINTT-2010)». Vol. 1. P. 8-10.

6. Maltsev, A.S. (2006) Intelligent Hybrid Decision Support Systems. Navigation: Sat. Scientific proceedings ONMA, Vol. 11. P. 74-86

7. Tsymbal, N.N. Buzhbetsky, R.Yu. (2006) Taking into account the limitations of the COLREGs-72 when choosing the ship-to-pass maneuver. Navigation. Vol. 11. P. 134138.

8. Burmaka, I.A. (2006) Polycriteria process control with satisfaction. Navigation. - Vol. 12. P. 26-30.

9. Ermakov S.V. (2018) Emergency risk management based on forecasting and minimizing the influence of the human factor on the navigational safety of a vessel's navigation: $\mathrm{PhD}$ thesis, Kaliningrad, $208 \mathrm{p}$.

10. Borsuk, S.P. Ergonomic fundamentals of proactive qualitimetry of regularities to show a human official in aeronautical systems: $\mathrm{PhD}$ thesis, Kharkiv, $378 \mathrm{p}$.

11. Tikhonov, I. N. (2018) Methodological bases of polyergic safety of navigation and management of water transport facilities (central technology of safety) : PhD thesis, Kiyv, $441 \mathrm{p}$.

12. Smolentsev, S.V. (2016) Automatic synthesis of solutions for diverging vessels at sea. Bulletin of the State University of Maritime and River Fleet named after Admiral S.O. Makarov. № 2 (38). P. 7-15.

13. Pipchenko, A.D. (2017) Analysis of the accident rate of the world fleet 2005-2015. Navigation. Vol. 27. P. 159-168.

14. Vagushchenko, L.L. (2010) Support for decisions on disagreement with courts. 229 p.

15. Astrein, V.V. (2017), Methodology of analysis and synthesis of complex active technical systems and its implementation in the navigation safety : PhD thesis, , Krasnodar, 311 p.

\section{A.A. Zazirnyi, O. O. Aroslankin \\ COORDINATION OF TECHNICAL AND BIOLOGICAL SEGMENTS OF THE ERGATIC SYSTEM "SHIPMAN - SHIP" USING A FUZZY NEURAL NETWORK APPROACH}

The article analyzes the causes and consequences of dangerous situations during the movement of the vessel and determines the need for an individually adapted approach to support decision-making. An approach is proposed for the operational control and support of the boatmaster's actions, which is based on the use of an individually adapted neural network model of his activity, implements the features of managerial reactions in hazardous sailing modes. Such models make it possible to identify and intercept the boatmaster's errors in the process of implementing the decision. Predicting the accuracy of bringing the vessel to the 
terminal point of the maneuver trajectory based on the current state vector, ensures the timely determination of the situation. The complexity of the problem of predicting situations in dangerous control modes due to the determination of the navigator's errors arises from the impossibility of clearly stating the correspondence of changes in the input and output parameters of the state in which the control object is located or to which it seeks. The most important property of fuzzy neural networks, which indicates their great potential in predicting and supporting the actions of the navigator, is the possibility of parallel processing of information by all neurons. Due to this ability, with a large number of interneuronal connections, processing of a significant amount of measurement information, incoming measurement information in real time is achieved simultaneously. The structure and parameters of fuzzy neural network models are determined based on the processing of data from previous actions performed by a specific boatmaster on a specific ship, and are continuously updated as new data arrives. The classification of the navigator's errors when making decisions in the process of managing ships was used, which made it possible to develop procedures for responding to them. The proposed approach makes it possible to coordinate the technical and biological segment of the "boatmaster cydов ship" ergatic system and to reduce the influence of the human factor in dangerous situations during the movement of the vessel.

Key words: ship, navigator, situation of dangerous approach, navigation situation, ergatic system, human factor.

Зазирный А.А., Аросланкин А.О.

\section{СОГЛАСОВАНИЕ ТЕХНИЧЕСКОГО И БИОЛОГИЧЕСКОГО СЕГМЕНТОВ ЭРГАТИЧЕСКОЙ СИСТЕМЫ «СУДОВОДИТЕЛЬ - СУДНО» С ИСПОЛЬЗОВАНИЕМ НЕЧЕТКОГО НЕЙРОСЕТЕВОГО ПОДХОДА}

B статье проанализировань причины возникновения и последствия опасных ситуаций во время движения судна и определена необходимость применения индивидуально-адаптированного подхода для поддержки принятия решения. Предложен подход по оперативному контролю и поддержки действий судоводителя, в основе которого лежит использование индивидуально адаптированной нейросетевой модели его деятельности, реализует особенности управленческих реакиий при опасных режимах плавания. Такие модели позволяют осуществлять выявлять и перехватывать ошибки судоводителя в прочессе реализачии принятого решения. Прогноза точности приведения судна в терминальную точку траектории маневра на основе текущего вектора состояния, обеспечивает своевременность определения ситуации. Сложность задачи прогнозирования ситуаций в опасных режимах управления за счет определения ошибок судоводителя возникает из-за невозможности четкой постановки соответствии изменений входных и выходных параметров состояния, в котором находится или к которому стремится объект управления. Важнейшее свойство нечетких нейронных сетей, что свидетельствует об их большой потенциал в области прогнозирования и поддержки действий судоводителя, состоит в возможности параллельной обработки информации всеми нейронами. Благодаря этой способности при большом количестве межнейронных связей достигается одновременно обработка значительного объема измерительной информации, поступающей измерительной информащии в реальном масштабе времени. Структура и параметры нечетких нейросетевых моделей определяются на основе обработки данных предыдущиих действий, выполненных конкретным судоводителем на конкретном судне, и непрерывно уточняются по мере поступления новых данных. Использована классификация ошибок судоводителя при принятии решений в процессе управления судов позволило разработать прочедуры реагирования на них. Предложенный подход позволяет согласовать технический и биологический сегмент эргатической системь «судоводитель - судно» и снизить влияние человеческого фактора в опасных ситуачиях во время движения судна.

Ключевые слова: судно, судоводитель, ситуация опасного сближения, навигационная обстановка, эргатической система, человеческий фактор. 